\title{
SAPERE AUDE. ABOUT THE CONTRIBUTION OF ELDERLY PEOPLE TO CULTURAL LIFE
}

\author{
DANIEL MEYNEN \\ Translation: Annette Denton \\ Defunct Hochschule Holzen e.V, 79400 Kandern-Holzen, Germany \\ E-mail address: daniel.meynen@t-online.de
}

\begin{abstract}
Nicolaus Copernicus is shown as an ideal of senior students. He represents all the intellectual qualities that we connect with the spiritual movement of the Enlightenment. This movement has led to the unfolding of the sciences with all its good and bad consequences, to the appearance of natural rights and religious tolerance. The modern concepts of education, civil rights and the development of a critical general public are not conceivable without the ideas of the Enlightenment. But the idea of Enlightenment showed clearly two different faces during its development: One is showing the enlightenment of human beings and concerns the environment they are part of, whereas the other is showing the enlightenment about themselves. Both will be commented on. Without doubt we are in need of a new Enlightenment. It should teach us to trust our own spiritual capabilities, to look for a critical exchange with other minded people and other cultures, to create communities of free-thinking people and to create protected public spaces for critical thinking.
\end{abstract}

Key words: Nicolaus Copernicus, Immanuel Kant, different aspects of enlightenment, contribution of elderly people towards our common culture, intellectual honesty and courage

When asked about the contribution of elderly people to cultural life, my thoughts go spontaneously to Nicolaus Copernicus, the great Pole and European. He represents the long process towards the achievement of old age: he only started to write down the results of his research when he was 60 years old. They were published in 1543, just after he died at the age of 70 . His name stands above all for independent thinking and continuous search for the truth. Against the everyday appearance and the firm teachings of the philosophical and theological authorities of his time he developed the ideas of the heliocentric system that are nowadays so familiar to us. The name Copernicus stands for the courage to defend the recognised truth against internal and external opposition. His name also stands for universal education: he was a scholar of 
law and a natural scientist, a medical practitioner, a cartographer and an artist. This scholar and practitioner represents all the intellectual qualities that we connect with the spiritual movement of the Enlightenment: especially intellectual honesty and courage. Therefore I would like to talk about the Enlightenment's spiritual ideas, which have Copernicus as one of their forefathers and I would like to refer to the connecting theme of these ideas to explain the central contribution that elderly people can give to the development of our spiritual cultural life.

The word Enlightenment nowadays is connected with the desire to abolish conservative teachings which only rely on authority and the reorganisation of daily life based on views and insights that are based on the law of reason. The Enlightenment has become the key word for a spiritual and social movement of reforms. People have referred to the term of reason as the universal judgement and the spiritual fight that has been fought mainly directed against prejudices and superstition.

The ideas of the Enlightenment have led to the unfolding of the sciences, the appearance of natural rights and religious tolerance. The modern concepts of education, civil rights and the development of a critical general public are not conceivable without the ideas of the Enlightenment. But the idea of Enlightenment has shown more and more clearly two different faces during its development: One is showing the enlightenment of human beings concerning the environment they are part of and the other is showing the enlightenment about themselves.

\section{ENLIGHTENMENT CONCERNING NATURE}

The enlightenment concerning nature is the most common known aspect. It is forever connected to the names of the Pole Nicolaus Copernicus (1473-1543), but also to the name of the German Johannes Kepler (1571-1630) and the Italian Galileo Galilei (1561-1642) and the ideas of modern progress, natural sciences and the civilian technical development, whose forefather is the English Francis Bacon 1561-1626. The enlightenment concerning nature shall liberate from superstition, from dogmatic prejudices and the blindly accepted ideas of nature, which hinder the progress of mankind. It shall take away the blindfold from the eyes, which prevents us from seeing the world how it is. According to Copernicus: Who should not be led to admiration of the omniscient architect through observation and the spiritual contact with the heavenly order of the world edifice which is led by divine wisdom!

Whereas people in the Middle Ages believed that the sun rotated around the earth, the knowledgeable person today knows that the earth rotates around itself and around the sun and that it represents only a tiny part in the galaxy of our Milky Way which spreads out into the cosmos together with billions of other galaxies. And it is not a distant merciful god who created mankind and 
the earth, as people in the old times believed, but the power of the evolution that is part of our existence which created the elements and living cells from star dust and indivisible first particles which themselves developed into plant cells and living creatures. The human himself is not a dual being and not made out of dead bodies and living spiritual souls as Descartes and people in the area of rationalism believed, but a human being who is capable of action and recognition, a rational being who has the power of reason and thinking given by evolution. The Enlightenment therefore freed people from the intolerable prejudices of geocentric thinking, the belief in the story of the creation and the cartesian dualism. It prepared the ground for astrophysics, the theory of evolution and modern brain research.

All this happened under the maxim to free the life of humans from the restraints of nature and the tribulations of daily work and instead to conquer nature and make it work as a servant for themselves. Nature should not rule humans but humans should rule nature. The slave of nature should become its master. The idea of progress which is connected with the Enlightenment promised a paradise on earth, a world without work and tribulations. It promised a development to a higher, better, healthier life, from a poor life full of tribulations to a perfect life. And who should doubt that quite a few things have changed in this direction under the aegis of progress and Enlightenment. Whereas the Enlightenment concerning nature was only possible because of the pioneering inventions of the compass, gunpowder and printing press, nowadays it is followed by new forms of domination of nature by radar, nuclear power and digital media. Who of the beneficiaries of civil progress would want to live without electricity, washing machines, electric cookers, cars, television, computers or the help of modern medicine? But should this mean that our life has come nearer our promised time of paradise? Not at all.

Normally we describe the time between 1650 to 1800 as the time of Enlightenment. It is the age of Vicos, Voltaire, Lomonossow, Lessing and Kant. In the two centuries that followed, humankind experienced a nearly unimaginable demographic development from one billion to 7 billion people, global warming with unpredictable consequences for all continents, a gigantic destruction of the environment and an uncontrollable pollution of the world's oceans. In the two world wars Europe, the continent where the ideas of progress and Enlightenment started, became the scene of the most horrible struggles and death camps of all humankind with more than 70 million victims of war

Many modern thinkers therefore have declared the project of Enlightenment as unsuccessful. In Germany the criticism is mainly connected to the names of Horkheimer and Adorno and their book: Dialectic of Enlightenment; in France it is the later published book of Albert Camus The Rebel. Criticism is directed at the fact that Enlightenment only leads to a technical perfection of instruments and weapons but not to an optimal way of living and thinking. We are only enlightened about the secrets of nature but not about the conditions of human life. We have learnt to cram our world with nuclear powered and 
remote controlled systems but we did not ensure that the social and political development of human beings became the controller of our system. The technical perfection of living together on a more and more crowded planet was more important than the human development, that means to look for ways to secure a peaceful development of mankind. We have put too much confidence in the unavoidability of the ideas of progress and we have not given enough importance to the human being as the real representative of Enlightenment.

\section{ENLIGHTENMENT OF PEOPLE ABOUT THEMSELVES}

Therefore I will now bring to your attention the neglected other face of Enlightenment that belongs to the person who enlightens about himself. This face has been drawn in particular by the other great thinker of Enlightenment, Immanuel Kant. His fundamental explanation of this term which was accepted in the following period of time can be found in a short script which he wrote in 1784 in Königsberg-Krolewiec, now Kalingrad, as an answer to the question "What is Enlightenment?".

"Enlightenment", says Kant, "is the escape of humans from their self inflicted immaturity . Immaturity is the failure to use your intellect without the guidance of others. This immaturity is self inflicted if the reason for this lies not in a lack of intellect but in the indecision and the courage to use your own intellect. Sapere aude! Have courage, to use your own intellect ! This is the motto of Enlightenment" (Kant, 1784, p. 35).

In these sentences the thoughts of Enlightenment are not any more directed at the objective nature but in the first place at the subjective capabilities of intellect and reason of the rational person. A different world of Enlightenment is therefore opening. Here, instead of the two ideas of Enlightenment and progress, the two ideas of Enlightenment and humanity are leading. Normally we struggle to gain knowledge about ourselves and about things in front of our eyes. And still, since ancient times, it is the perfect example for high wisdom to gain knowledge about yourself. "Discover yourself", "Become the one you are", were words that every visitor to the temple of Delphi could read, chiselled in stone, at the entrance to the temple. What path do we have to take to come towards our own enlightenment?

\section{SAPERE AUDE}

In order to guide us this way, Kant uses an old Latin aphorism that brings together the word courage with the word thinking: "Have the courage to think for yourself". Sometimes it is easier to say: "Think for yourself". But this simple translation can easily lead to misunderstandings. What does the Latin word sapere mean? 
Sapere has the meaning: "to taste", "smell", "sniff", "scent", "foresee". It is the root from where sapientia (wisdom) and sapiens (wise man) derive. The wise man can judge the situation he is in. He is alert, attentive, takes notice of what is happening around him, understands the signs and correlations between his life and the world. He is aware and understands the appearances which he is confronted with. According to neurologists the cerebrum of humans has developed from the organ of smell. The wise man can sniff out what is important for his core of existence. A human is not wise if he understands everything and everyone, he is not an omniscient but somebody who has a feeling for what is central and of a deeper meaning for him. His "reason" is the organ he uses to "take in" the world and help him to find his way and to act according to its inner rules.

In the Enlightenment sapere aude does not therefore simply mean: Have the courage to think in a logical or sociological way, but: Have the courage to understand your situation as unvarnished as it is presented to you. Find out yourself about things that concern you and act following the principles of reason. It is the fundamental principle of the Enlightenment that the laws of the cosmos and the laws of reason are the same. If you follow this principle you cannot go wrong. If you think for yourself you are in accordance with the spiritual laws which guide all self-thinking individuals.

These laws connect humans more than anything else. Because the feelings, cultures, languages and religions of mankind are very different as we all know; but the thoughts and the intellectual elemental pattern, which develop during our adolescence, are for everybody the same, no matter what language or culture we belong to. Without them communication across language barriers is absolutely unthinkable.

On the other hand you could argue that people are normally selfish and the proposition "Think for yourself" could be understood as: "Think in your own small place for yourself". But the opposite of this is meant by the fundamental ideas of the Enlightenment. "Think for yourself" does not mean "Give people with a different opinion no attention" but the opposite: "Think for yourself" leads necessarily to the consideration of others because the other person we have a dialogue with is in other words the assistant of the birth of our own thinking and he is the corrective we need to examine our own thoughts critically. Everybody needs somebody else in order to free himself of his own prejudices. And everybody needs others in order to examine his own moral convictions.

Another misunderstanding would be to interpret "Think for yourself in the sense of "Keep your thoughts for yourself. If you tell others you will expose yourself and put yourself unnecessarily in danger". This opinion is also in contradiction to the ideas of Enlightenment. It is an essential part of Enlightenment to make use of your good sense in public. A critical examination and cleansing of our thoughts is only possible if we expose them to the public eye. By this is meant the general public and people of a different opinion. "To think 
for yourself, the public and criticism" are the undisputable principles of the Enlightenment.

The aphorism of "To think for yourself" has also a second part. "Aude. Be courageous!" Why is courage part of thinking? Kant mentions laziness and cowardice as the main causes of self inflicted dependence. It is so easy to be dependent and to rely on experts. When I have a book, a doctor or a clergy man, I am relieved from the effort to find a solution myself for my questions and difficulties. Kant thinks that by far the biggest number of people finds thinking for themselves too tiring and too dangerous and that we therefore prefer to live as an dependant person with a guardian. The dependence has become unwillingly our second nature. For the individual person it takes more effort to free himself from dependency than for a community where members instruct each other.

In order to achieve this kind of Enlightenment only one condition is necessary: namely political freedom, in other words the freedom that allows us to make public use of our common sense in all areas. Furthermore you need courage, the courage to expose yourself and to appear in public. It interprets the general use of common sense as follows: to be able to express your own thoughts freely and without fear of reprisals in front of the whole intellectual community, so that everybody is able to examine them. No class and no generation have the right to dictate to a lower or other class what to think. Everybody has the right to examine the facts himself. If the authorities are in need of a rule in order to scrutinize a law they imposed on people, the rule should follow the answer to the question if people would have imposed such a law themselves.

The importance of Enlightenment for Kant is manifested in his opinion that the denial of Enlightenment means " to violate the holy human rights and trample on them". If not even the people are allowed to take their own decisions, then even less a state authority should be allowed to decide for the people. For the law making reputation of any authority is based on the fact that it combines the entire will of the people in its own. When he was asked, he continued, whether we lived already in an enlightened period of time he would answer: No, not yet, but we live nevertheless in an age of Enlightenment, which means in an age where people make enlightenment about themselves one of their duties.

It is obvious that this second side of Enlightenment has been undeveloped in the last two centuries. There were not many countries in which the creation of an independent public opinion was allowed. Until today the number of societies and countries in which citizens were able to develop an independent culture and come to an agreement with each other about the objectives of living together in a human way is not very high. In opposition are not only security and political interests but also above all economic interests (e.g. of the owners of media). Every authority is scared of losing power to an independent and critical general public and prefers to invest in external security instead of a joint 
search for a sensible solution to the problems. If this increased external security is not joined by a likewise increased internal spiritual strength which has developed from an exchange of ideas and discussion, then the result will be a hardening towards the outside and an impoverishment on the inside which will lead to the danger of new forms of totalitarianism and dictatorship.

Without doubt we are in need of a new Enlightenment. It should teach us to trust our own spiritual capabilities, to make the effort of thinking, to look for a critical exchange with other minded people and other cultures, to create communities of free thinking people and to create protected public spaces for critical thinking. Only a worldwide community of critical thinking people can succeed to save our planet from ruin. We all know that thoughts without action do not lead to anything, but action without thinking will end in a disaster which we have witnessed all too often.

I do not mean by this that injustice, suffering, and death could be abolished from the world. The heavenly world, Arcadia, we look for is a utopia, as we know. We learn everywhere, that the world, as it is, has no meaning, unless people take action. But you can act against self inflicted dependency, madness, superstition and against violence in the name of madness. Therefore we are in need of enlightenment about ourselves. We are in need of intellectual incorruptibility and clarity. We are in need of courage to examine the insights that we have come to during our lifetime and stand by them. We are in need of an educated and experienced pressure group which has the interests of the general public in mind. Would this not be the most important factor that elderly people could contribute towards our common culture?

Even if none of us can reach the greatness of Nicolaus Copernicus or Immanuel Kant, we are all given the capabilities of looking for the truth and of using our common sense truthfully and courageously.

\section{REFERENCES}

[1] Kant, I. (1784). Beantwortung der Frage: Was ist Aufklärung?[Answering the Question: What is Enlightenment?]. Berlin: Preußische Akademie der Wissenschaften, Kant's gesammelte Schriften VIII. 